\title{
CHEMICAL CATALYTIC AND BIOCATALYTIC PROCESS OF CLOVE OIL DERIVATIVES REVIEW
}

\author{
TURUNAN DARI MINYAK CENGKEH DENGAN PROSES KATALIS DAN \\ BIOKATALIS (TELAAH)
}

\author{
Silvester Tursiloadi, Nina Artanti, Anny Sulaswatty \\ Pusat Penelitian Kimia - LIPI Kawasan Puspiptek Serpong, Tangerang, Indonesia 15314 \\ Email : tursiloadi@gmail.com
}

Diterima: 13 Maret 2015, Revisi:20 Maret 2015, Disetujui: 07 April 2015

\begin{abstract}
In 2011, Indonesian clove oil supply reached about $75 \%(4,500$ of 6,000 tons $)$ of the world market. Utilization of clove oil and clove oil derivatives in aromatic chemical industry primarily as a mixture or additive of fragrances in the daily consumed product, such as perfumes, skin care products, deodorant, soap, shampoo, detergent, besides it is also used as an ingredient in the production of synthetic vanilla. The content of eugenol as the main compound in the essential oil in the clove flower, flower stalk and leaf have a range of $90-95 \%, 83-95 \%$ and $82-87 \%$ respectively. The compounds content in clove oil is divided into two categories, phenolics (eugenol) and non-phenolic (beta-caryophyllene) that can be derivatized with various chemocatalytic and biocatalytic processes. Separation of the compounds in clove oil can be conducted by adding $\mathrm{NaOH}$ with repeated distillation. This process produces two layers product, the first layer contains eugenol and $\mathrm{NaOH}$, while the second layer contains beta-caryophyllene. Derivatization of eugenol are conducted to produce various products such as vanilla, eugenyl ether, methyl ether eugenyl, eugenyl ethyl ether, eugenyl acetate, eugenyl cinnamate, dimmer eugenol and eugenyl benzoate, whereas derivatization of betacaryophyllene are conducted to produce products such as caryophyllene oxide, kobusan, glycols, alcohols caryophyllene, $\beta$-caryolanylformate and kovanilformate, klovanildiformate, caryophyllene ketol. Biocatalysis or biotransformation can be defined as the use of biological systems (intact cells, cell extracts or isolated enzymes) to catalyze the conversion of a compound into another. Besides the common chemocatalysis system for derivatization of clove oil and clove oil compound such as eugenol into other compounds some biocatalysis systems were also described in this paper.
\end{abstract}

Keywords: Clove oil, eugenol, beta-caryophyllene, derivatization, chemical catalysis, biocatalysis

\section{ABSTRAK}

Pasokan minyak cengkeh Indonesia ke pasar dunia pada tahun 2011 mencapai sekitar $75 \%$ (4.500 dari 6.000 ton). Pemanfaatan minyak cengkeh,dan turunan minyak cengkeh dalam idustri kimia aromatik terutama sebagai campuran atau aditif pewangi dalam produk yang dikonsumsi sehari-hari seperti parfum, produk perawatan kulit, deodoran, sabun, shampoo, deterjen, selain itu juga merupakan bahan antara dalam produksi vanili sintetis. Kandungan eugenol sebagai kandungan senyawa utama dalam minyak esensial dalam bunga, tangkai bunga dan daun cengkeh memiliki kisaran 90-95\%, 83-95\%, dan 82-87\%. Kandungan senyawa minyak cengkeh dibagi menjadi dua kategori, fenolat (eugenol) dan nonfenolat (beta-caryophyllene) yang dapat diderivatisasi dengan berbagai proses katalis kimia dan biokatalisis. Pemisahan kandungan senyawa minyak cengkeh dapat dilakukan dengan menambahkan $\mathrm{NaOH}$ dengan distilasi berulang. Proses ini menghasilkan produk dengan dua lapisan, pertama mengandung eugenol dan $\mathrm{NaOH}$, sedangkan lapisan kedua mengandung betacaryophyllene. Derivatisasi eugenol digunakan untuk menghasilkan produk seperti vanili, eugenil eter, metil eter eugenil, eugenil etil eter, eugenil asetat, eugenil sinamate, dimer eugenol dan eugenil benzoat. Sedangkan derivatisasi betacaryophyllene, untuk menghasilkan produk seperti oksida caryophyllene, kobusan, glikol, caryophyllene alkohol, $\beta$-caryolanilformat dan kovanilformat, klovanildiformat, caryophyllene ketol. Derivatisasi bisa dilakukan dengan menggunakan proses kemokatalitik dan biokatalitik. 
Makalah ini meninjau beberapa sistem kemokatalisis dan biokatalisis untuk derivatisasi minyak cengkeh dan komponen minyak cengkeh seperti eugenol menjadi senyawa lain. Biokatalisis atau biotransformasi dapat didefinisikan sebagai penggunaan sistem biologis (sel utuh, ekstrak seluler atau enzim terisolasi) untuk mengkatalisis konversi suatu senyawa lainnya. Selain sistem kemo katalisis yang umum digunakan untuk derivatisasi minyak cengkeh dan senyawa minyak cengkeh seperti eugenol menjadi senyawa lain, dalam makalah ini beberapa sistem biokatalisis juga dijelaskan dalam makalah ini.

Kata Kunci: Minyak cengkeh, eugenol, betakariofilen, derivatisasi, katalisis kimia, biokatalisis

\section{INTRODUCTION}

\section{Clove oil}

Indonesia is a very potential country for the development of the essential oil industry. In 2011, Indonesian clove oil supply, reached $75 \%$ (4,500 from 6,000 ton) of the world market ${ }^{(1)}$. Although the clove oil has also been developed for the medical and cosmetics field, however the general public recognized clove only as a spice for cooking and ingredient in cigarettes $^{(2)}$.

Clove oil is an essential oil obtained from cloves (Eugenia aromatica or also known as Syzygium aromaticum) that belongs to the family of Myrtaceae ${ }^{(3)}$. Eugenol is the major component in the essential oils from the clove flowers, flower stalks and leaves which the content have range 90-95 \%, 83-95\%, and 82-87\% respectively ${ }^{(4)}$.

The oil yield ranged between 2-12\%, depending on the type and circumstances of raw materials, materials handling, as well as the manner and conditions of distillation ${ }^{(5)}$. Constituents of clove oil can be divided into two groups. The first group is a phenolic compound which eugenol is the major component. The second group contains compounds that are non-phenolic such as $\beta$ - caryophyllene, $\quad \alpha$-kubeben, $\quad \alpha$-kopaen, hulumen, $\delta$-kadien, and 1,3,5-trien $\operatorname{Kadina}^{(6)}$.

Analysis of the components in clove oil (density at $30{ }^{\circ} \mathrm{C}=0.9994^{(7)}$ ) using gas chromatographic showed two major peaks, eugenol $(71.5 \%)$ and $\beta$-caryophyllene (28.0 $\%)$.

\section{Eugenol}

Eugenol is a compound from the class of oxygenated hydrocarbons with the molecular formula is $\mathrm{C}_{10} \mathrm{H}_{12} \mathrm{O}_{2}$. Chemical nomenclature of eugenol includes 4-allyl-2methoxy-phenol, 1-hydroxy-2-methoxy-4allyl benzene or 4-allyl guaiacol that are not optical $^{(3)}$. Eugenol, is volatile, colorless or slightly yellow color and has a bitter taste. Eugenol may turn brown if in contact with air due to oxidation event ${ }^{(8)}$. Eugenol is soluble in alcohol, chloroform and ether, and sparingly soluble in water. Eugenol has a molecular weight of $164.20 \mathrm{~g} / \mathrm{mol}^{(5)}$. Physico-chemical properties of eugenol based on Leody standard $1970^{(9)}$ and based on EOA standards for trade ${ }^{(10)}$, are presented in Table 1. Eugenol is a phenolic compound containing at least one hydroxyl group and more are forming ethers, esters or glycosides rather than independent compounds. The solubility of an ester or ether of phenol compounds in water is lower than the phenols compounds, while glycoside compounds are more soluble in water ${ }^{(11)}$. In a state of pure compound, simple phenol is a colorless solid, but usually oxidized and has dark color if it reacts with air. Water solubility increases with the increasing number of hydroxyl groups, but the solubility in polar organic solvents are generally high. Phenol has a small solubility in water, however it soluble in sodium hydroxide solution ${ }^{(11)}$. 
Table 1. Eugenol Physico Chemical Properties

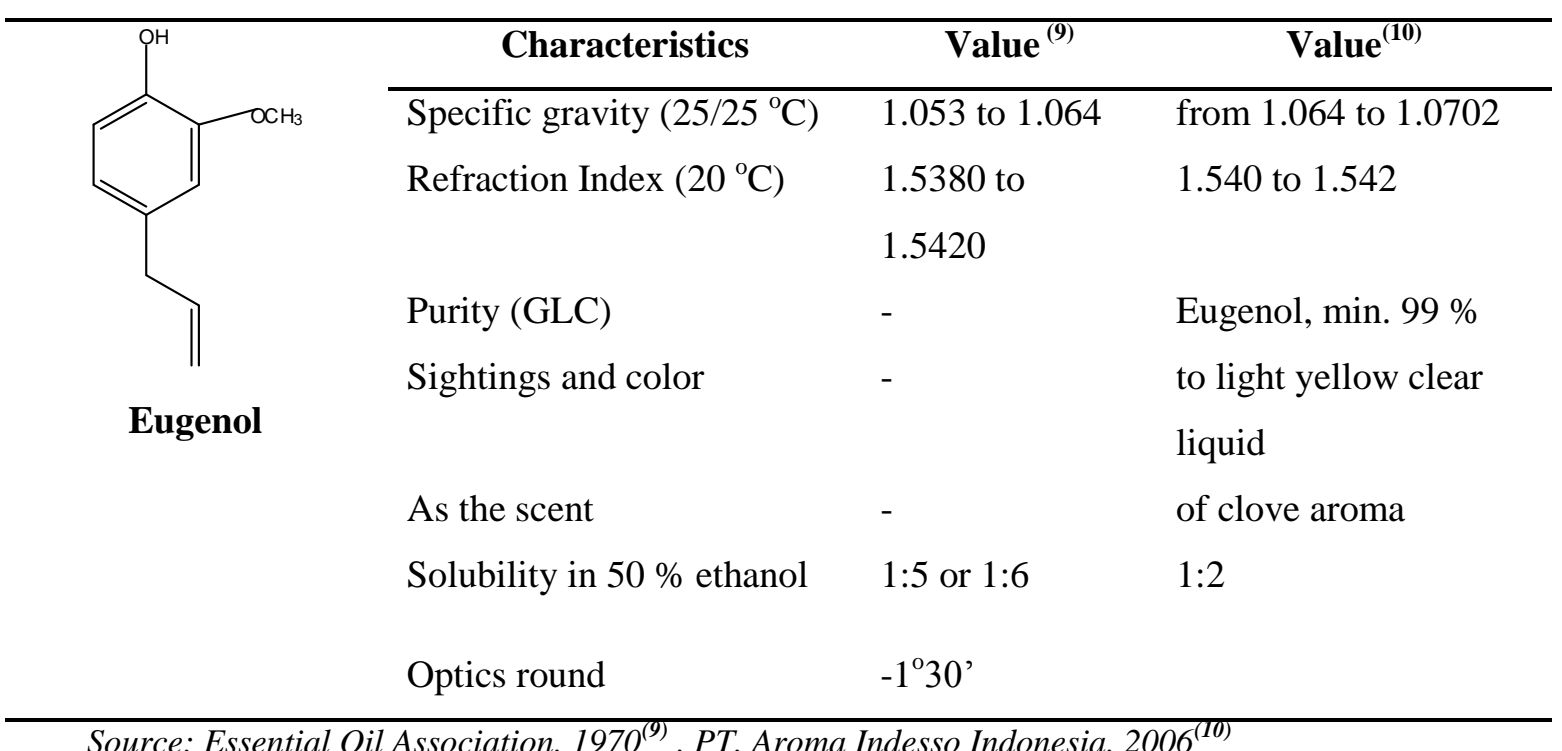

\section{RESULTS AND DISCUSSION}

\section{Derivatization of Eugenol by Chemical Catalysis}

\section{Dimer Eugenol}

Focus will be on synthesis of dimer eugenol that can serve as an anti-oxidant and anti-inflammatory drug. The dimerization of eugenol is an oxidative phenolic reaction that can be carried out with solid acid or metal complex catalyst. These nanocatalysts are characterized as heterogenous catalyst and have advantages in the separation stage of the product which will be very useful for future industrial process. It has been reported that the dimer of eugenol, dehydrodieugenol has known to have less cytotoxicity and greater anti inflammatory activity than parent eugenols $^{(12-15)}$.

A famous scientist that have developed this particular field in the industrial market is the 2001 Nobel laureate, Ryoji Noyori, for his discovery of an asymmetric catalyst - chiral BINAPrhodium complex which is currently used by Takasago Corporation for commercial industrial synthesis of menthol ${ }^{(16,17)}$. With his catalyst, stereoselective menthol is produced and side-products are eliminated. The reaction is selective hydrogenation.

Oxidative phenolic reaction using nanocatalysts can undergo in many pathways and produce a mixture of products. With the application of highly selective heterogeneous nanocatalysts, the reaction can be control for a specific pathway and eliminate the mixture of products. Heterogeneous catalysts are also easily separated from the product. Reaction pathways of oxidative phenolic reactions is displayed in Figure 1.

Dimerization involves the attack of a phenolic radical. The radical formed will undergo resonance and combine with other radicals in a coupling reaction. In this stage the stability of the catalyst is needed for the efficiency of reaction. The reaction can take place with an acid or metal complex catalyst which is able to accept electrons from the phenolic compounds ${ }^{(17,19,20)}$. 


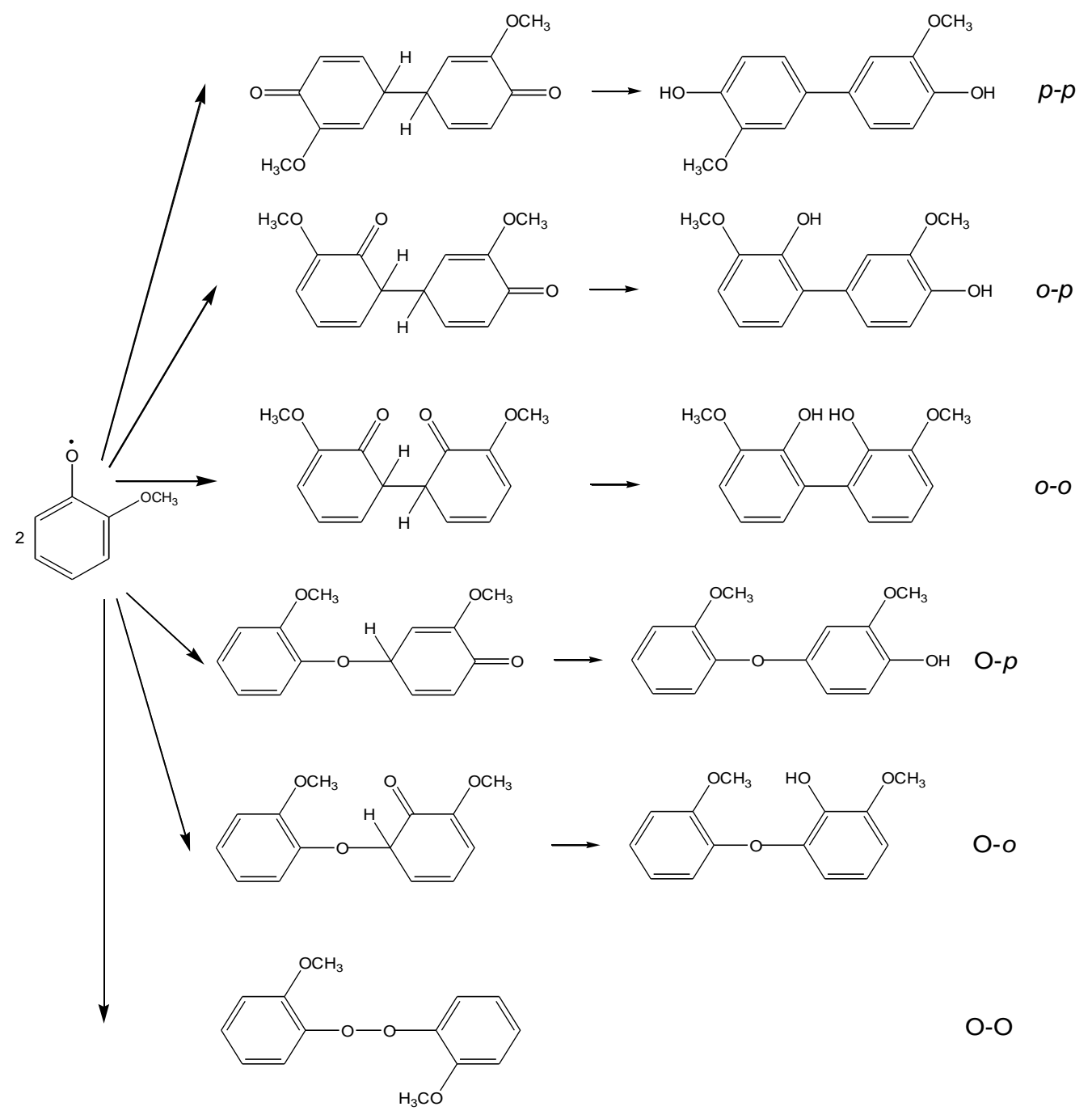

Figure 1. Reaction pathways of oxidative phenolic reactions ${ }^{(18)}$

Heterogeneous nano-catalysts prepared will be a solid metal-complex and solid acid catalyst. A solid metal-complex is inorganic-organic hybrids have been gaining much attention from the viewpoint of functional materials. 1,2 Host-guest interactions between inorganic layer compounds and organic compounds give a great potential to construct novel nanostructural materials ${ }^{(21)}$. Among the inorganic layer compounds, the clay minerals have prosperous properties such as facile intercalation of polar guest molecules and cations, reversible lamination and delamination, and swellability ${ }^{(22,23)}$. The metal-complex catalyst by the intercalation of organometal-complex into clay as summarized in Figure 2.

The concentration of hydrogen or acid can increase indefinitely since water mixes in all proportions with acids. Besides, with suitable equipment, we can prepare 'pure' acids with no water in them - most likely in conditions that are not standard. Acids whose $\mathrm{pH}<0$ are called super acids (Cotton, Wilkinson, \& Gaus (1987: 221) $)^{(24)}$. Super acids are used to provide protons, and are believed even to force substances to accept protons. Similarly, there are super bases. 

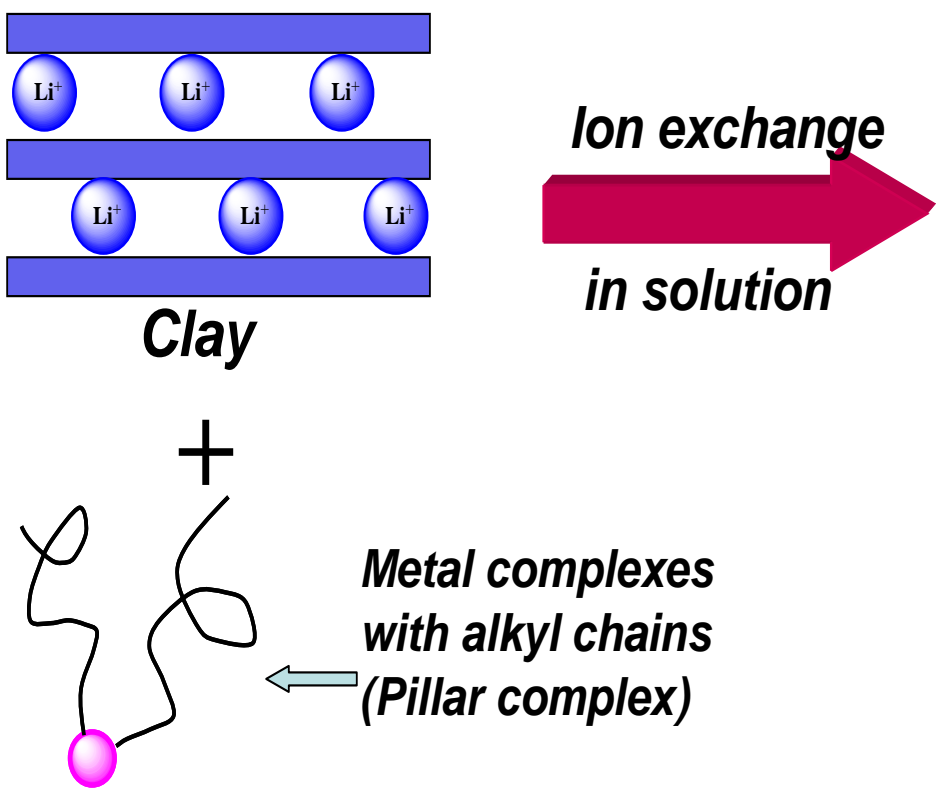

Figure 2. Intercalation of metal complexes into clay ${ }^{(21)}$

According to Cotton, Wilkinson, \& Gaus (1987: 221) $)^{(24)}$, super acids are necessarily non aqueous (i.e., have little or no water) since the acidity of any aqueous system is limited by the fact that the strongest acid that can exist in the presence of water is $\mathrm{H}_{3} \mathrm{O}^{+}$. In that system, a stronger acid than $\mathrm{H}_{3} \mathrm{O}^{+}$loses its proton to $\mathrm{H}_{2} \mathrm{O}$ to form more of $\mathrm{H}_{3} \mathrm{O}^{+}$. To measure this kind of acidity, one has to go beyond the normal $\mathrm{pH}$ scale.

Clay minerals are hydrous phyllosilicates predominantly composing clays (rocks). These are hydrous silicates of $\mathrm{Al}, \mathrm{Mg}, \mathrm{K}$, and $\mathrm{Fe}$, and other less abundant elements. Clay minerals are extremely fine crystals or particles, often colloidal in size and usually plate like in shape ${ }^{(25)}$. The very fine particles yield very large specific surface areas that are physically sorptive and chemically surface active. Many clay mineral crystals carry an excess negative electric charge owing to internal substitution by lower valent cations, and thereby increase internal reactivity in chemical combination and ion exchange. This property makes clay active as catalyst.

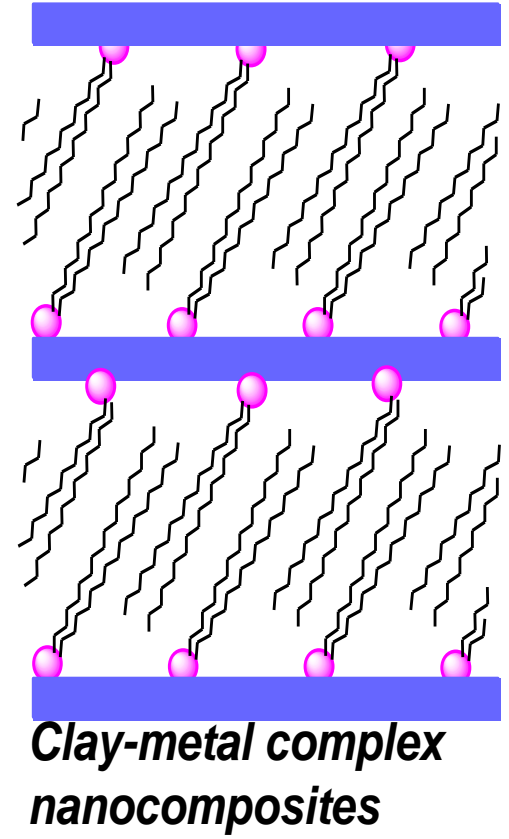

With intercalation of metal complexes into clay, a new property of material will be produced, having higher surface area and particular active sites ${ }^{(26)}$. The preparation is described as below. Superacid catalysts can be prepared by several approaches: liquid superacids supported on suitable carriers, a combination of metal halides with inorganic salts such as $\mathrm{AlCl}_{3}-\mathrm{Ti}\left(\mathrm{SO}_{4}\right)_{3}, \mathrm{AlCl}_{3}-\mathrm{CuCl}_{2}$ etc, per fluorinated resin sulfonic acid such as Nafion-H, and sulfate-promoted metal oxides such as $\mathrm{SO}_{4}{ }^{2-} / \mathrm{ZrO}_{2}, \mathrm{SO}_{4}{ }^{2-} / \mathrm{TiO}_{2}$, $\mathrm{SO}_{4}{ }^{2-} / \mathrm{Fe}_{2} \mathrm{O}_{3}{ }^{(12-20,25-31)}$.

Among these, sulfate-promoted metal oxides have been found to exhibit excellent catalytic properties for a number of acidcatalyzed hydrocarbon reactions. These catalysts, especially those of the sulfated zirconia type, are able to catalyze the isomerization of short linear alkanes at relatively low temperature (below 150 $\left.{ }^{\circ} \mathrm{C}\right)^{(27)}$. Even though it is accepted that the presence of sulfate species with covalent $\mathrm{S}=\mathrm{O}$ bonds on the oxide surface is necessary to obtain superacidity ${ }^{(6)}$, the exact nature of the catalytically active sites remains an open question in the literature. 
Thus, it is suggested that the superacid centers are Lewis sites associated to the metal cation $^{(7)}$, whose acid strength is strongly enhanced by an electron induction effect of $\mathrm{S}=\mathrm{O}$ in the sulfur complex, as is shown in figure 3 , scheme 1 . Others have suggested that the Lewis and Bronsted sites generated from adsorbed water molecules (Figure 3, scheme 2) are responsible for the catalytic activity. These Bronsted sites are easily interconverted to Lewis sites by evacuation at temperatures above $150{ }^{\circ} \mathrm{C}$.

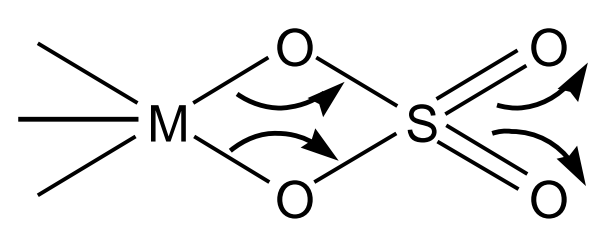

Scheme 1

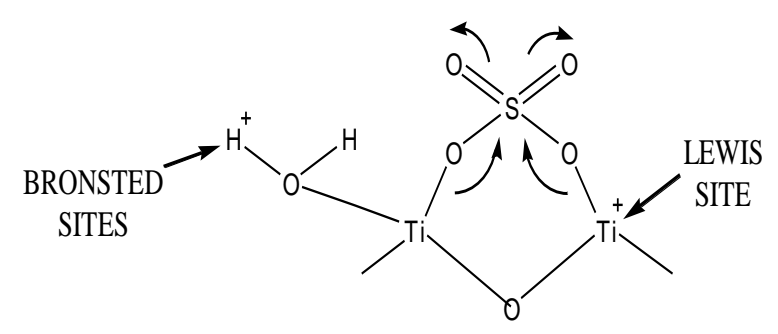

Scheme 2

Figure 3. Formation of superacidcatalyst ${ }^{(26)}$

Synthesis of eugenol dimer from clove oil, which has known to have less cytotoxity and higher anti-inflammatory activity than that parent eugenols ${ }^{(19,20)}$. The dimerization is an oxidative phenolic reaction, which yields many undesired side products $^{(19)}$. Therefore, a highly selective nanocatalyst is needed for the efficiency of synthesis. In designing and synthesizing new solid inorganic catalysts the aims are to maximize surface area, activity, selectivity, longevity, and durability.

Application of these catalysts in the nanoscale for future processes and synthesis will develop the nanotechnology field and industrial sector, particularly the production of pharmaceuticals. In this project, Eugenol dimer from clove oil will be provided throughout organic syntheses, and subjected into body samples, in order to find out whether they have greater anti-oxidant and anti-inflammantory activity that parent eugenol. Fujisawa et al. (2004) simulated the dimerization by computer-aid synthesis and concluded that they have higher antiinflammatory activity ${ }^{(16)}$.

\section{Reaction Mechanism of dimerization of Eugenol}

Reaction mechanisms that occur in the process of dimerization of eugenol is called oxidative coupling reaction in which the formation of free radicals in the compound eugenol eugenol compounds for coupling two radicals into a single unit called eugenol dimer. The mechanism of free radical reactions eugenol dimer formation through reaction stages are initiation (beginning), propagation (propagation), and termination (termination) $^{(29)}$. Marques et al. (1997) revealed that functional groups $\mathrm{OH}$ is attached to the bezene ring (phenolic group) has an important role in the oxidative coupling reaction. Molecules that do not have functional groups $\mathrm{OH}$ dimerization reaction will not occur or takes a very long time in order to form a dimer ${ }^{(30)}$. The mechanism of the reaction is as follows:

a). Initiation, i.e. separation into two homolytic $\mathrm{H}_{2} \mathrm{O}_{2}$ free radical $\mathrm{HO}^{*}$

$$
\left.\left(\mathrm{TiO}_{2} / \mathrm{SO}_{4}+\mathrm{H}_{2} \mathrm{O}_{2} \rightarrow \mathrm{TiO}_{2} / \mathrm{SO}_{4} \ldots . . \mathrm{H}_{2} \mathrm{O}_{2} \rightarrow \mathrm{TiO}_{2} / \mathrm{SO}_{4}\right)_{\mathrm{HO}^{*}}^{\mathrm{HO}}\right)
$$

Figure 4. Reaction Mechanism of Free Radical Initiation Phase ${ }^{(30)}$

The catalyst forms a complex with hydrogen peroxide which is then split into 
two hydroxyl radicals. Two hydroxyl radical is attached to the metal cluster peroxide so that it will produce a reaction intermediate. According to the 2004 study, hydroxyl radicals will oxidize phenolic compounds into phenoxy radicals which are quite stable because it can resonate compared with methyl or alkyl radicals ${ }^{(\mathbf{3 1})}$. The reaction is favored by radical dimerization reaction to form. Dimerization reaction can produce a number of dimeric dehydrogenase of phenoxy radicals, due to the unpaired electrons, which are on oxygen. The ability of the catalyst breaks down the hydrogen peroxide compounds are attached to the metal catalyst. These metals act as an electron storage media from the $\mathrm{H}_{2} \mathrm{O}_{2}$ thus losing stability and turned into two compounds. $\mathrm{OH}$ radical that there is one unpaired electron ${ }^{(32)}$. The presence of substituent $\mathrm{OCH}_{3}$ (methoxy) and vinyl (tails eugenol) leads to steric factors (obstacle space) so the possibility of coupling the position is smaller than the ortho position of the $\mathrm{OH}$ group has a lower steric factors. Low level of steric factors would be very easy to react with other compounds so that the condition of the ortho position of the phenoxy radical will meet with the other ortho position and formed two monomer compounds ${ }^{(30)}$.

b). Propagation, namely the propagation of free radicals in the main compound of the free radicals formed during initiation. Phenoxy radical resonance mechanism in all parts of the compound eugenol as shown in Figure 5.

c). Termination, the termination of free radical reactions in the presence of inhibitors that react with reactive free radicals in the same position so as to form reactive free radicals and relatively stable. The mechanism of free radical reactions in the termination phase can be seen in Figure 6.

According to Dias in $1998^{(33)}$, although from the phenolic reaction it has been established that the coupling is always in an ortho or para position to the phenolic hydroxyl group, observation was also conducted to see the possibity of other combinations, namely O-p and O-O. However, the combination is generally not possible because of the instability of peroxide produced, their selectivity of the catalyst and the presence of steric factors.
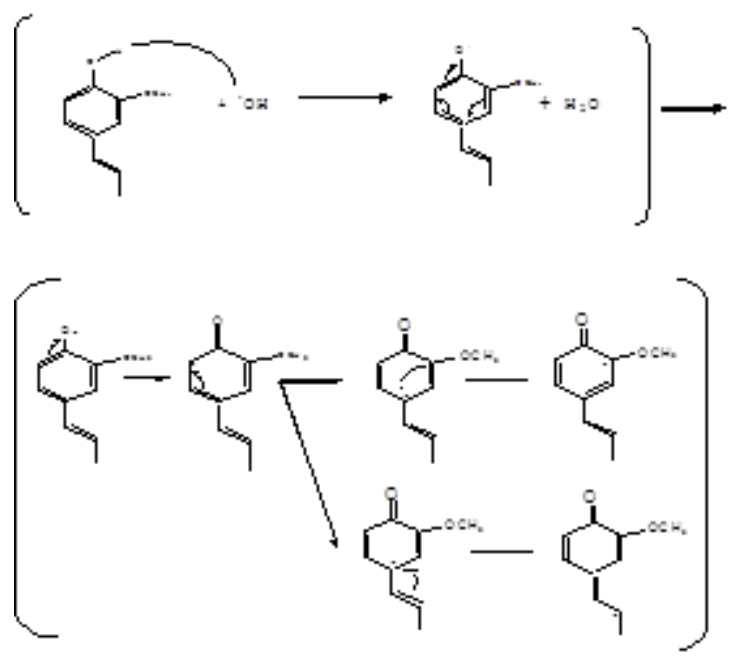

Figure 5. Resonance Mechanism in Phase Free Radical Propagation ${ }^{(29)}$

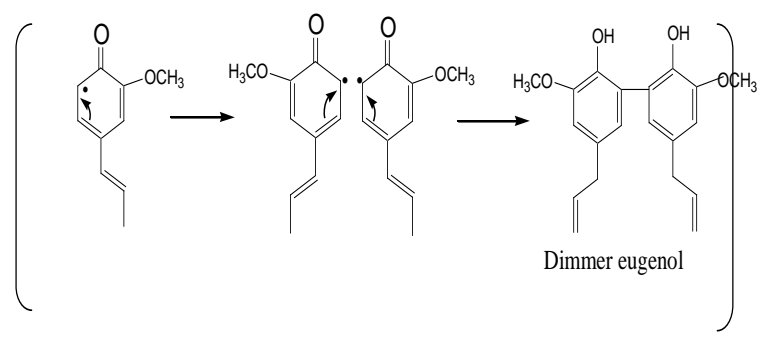

Figure 6. Reaction Mechanism of Free Radical Termination Phase ${ }^{(29)}$

\section{Vanillin}

Some ways of making vanillin has been known. One of the procedures used to produce vanillin in a large scale is a method of CIBA. In this method eugenol reacted with $\mathrm{KOH}$, nitrobenzene in the autoclave. $\mathrm{C}_{4} \mathrm{H}_{10} \mathrm{O}_{3}$ solvent used to carry out the isomerization of eugenol into isoeugenol with $\mathrm{KOH}$, and dimethylsufoxide (DMSO) 
was used as a medium for the oxidation of isoeugenol to vanillin with $\mathrm{KOH}$ and nitrobenzene. Purification of vanillin initially performed in a vacuum distillation and then recrystallized from hot water ${ }^{(28)}$. The reaction is shown in Figure 7.

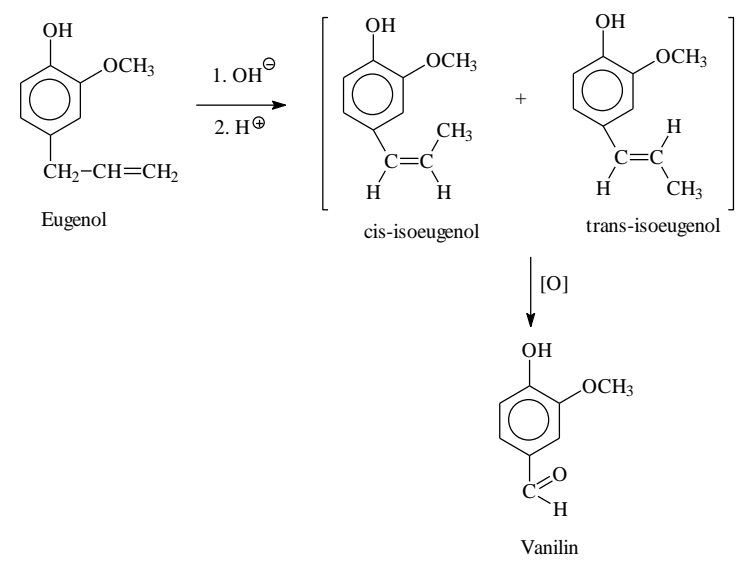

Figure 7. Reaction formation of vanillin ${ }^{(28)}$

\section{Eugenyl ether}

Most common methods for converted hydroxy compounds into ether derivative namely the reactions of metal, usually sodium salts, the alkyl halide or halides arakyl. This reaction is known as the Williamson ether synthesis. In the following discussion first presented eugenol converted into sodium eugenoxide by reaction with a solution of alcoxide in alcohol. Following ether compound formed by the reaction using alkyl halides or arakyl, sometimes the reaction takes place at room temperature.

$$
R O^{-} \mathrm{Na}^{+}+R^{\prime} X \rightarrow R O-R^{\prime}+\mathrm{NaX}
$$

$R^{\prime}$ is a primary alkyl group or a benzyl group and $X$ is $\mathrm{A}, \mathrm{Br}$ or $\mathrm{Cl}$

Formation eugenyl methyl ether (4-Allyl-veratrol, methyl eugenol)

Eugenyl methyl ether is very widely used as a perfume composition with oriental characters. It smells softer than eugenol, which is why the agriculture methyl ether can be used to attract male fruit flies Docus dorsalis. By using the method was prepared by Sastrohamidjojo, $(1981)^{(34)}$ known that the first peak is eugenol $(81.5 \%)$. The second peak is 1allyl-3-ethyl-4-hydroxy-5-methoxy benzene (18\%) which is a byproduct of the methylation reaction. Results eugenyl approximately $90.6 \%$ methyl ether theoretically if eugenol and adverse outcomes can be obtained taken into account.

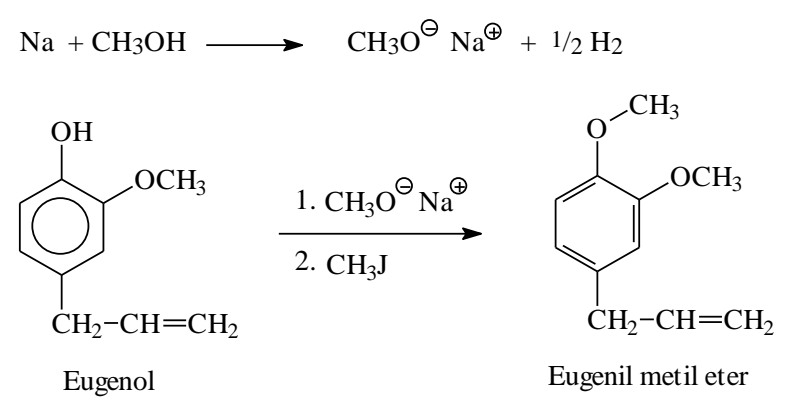

Figure 8. Reaction Formation Eugenyl Methyl Ether $^{(12,35)}$

\section{Isolation caryophyllene}

The top layer of the reaction product of clove oil and $\mathrm{NaOH}$ were already separated with the bottom layer containing caryophyllene extracted with petroleum ether. After the petroleum ether removed, the residue was distilled under containing caryophyllene by reduce pressure. Fraction with boiling point $85-102{ }^{\circ} \mathrm{C} / 6 \mathrm{mmHg}$ accommodated (crude caryophyllene). Originally distinguished name caryophyllene above three names, namely $\alpha$-, $\beta$-and $\gamma$ - caryophyllene ${ }^{(36)}$. A-name is replaced with the name caryophyllene humulen (I), $\beta$ - caryophyllene called caryophyllene (II), $\gamma$-caryophyllene called isocaryophyllene (III) as shown in Figure 9.

Caryophyllene was analyzed by using a combination of gas chromatography and mass spectrometry showed eight peaks. Six peaks were identified ${ }^{(37)}$. The main component is a $\beta$ - caryophyllene. 


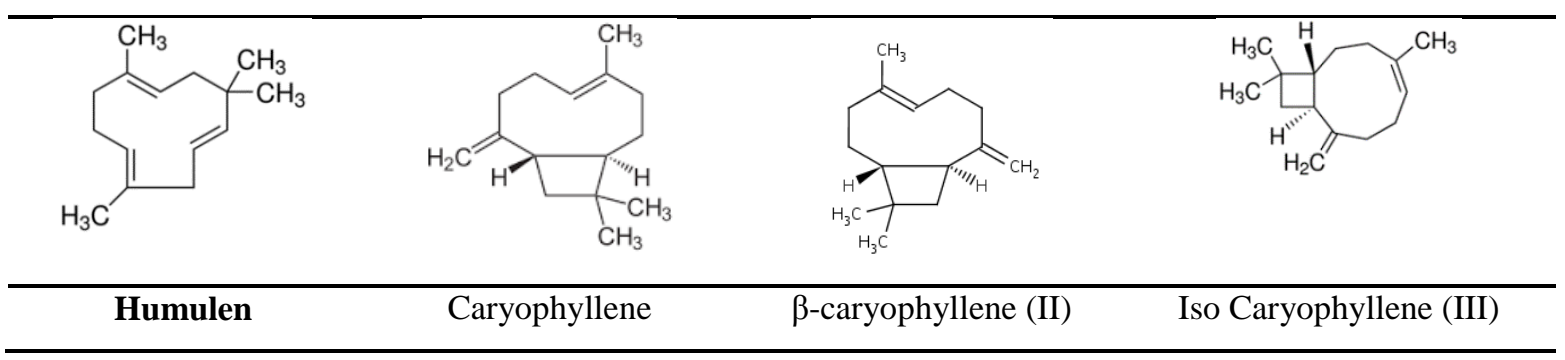

Figure 9. Structure of Caryophyllene ${ }^{(36)}$

\section{Formation of Some Caryophyllene Derivatives}

Conversion caryophyllene to caryophyllene oxide. In general epoxidation performed using peroxybenzoat acid, $\varphi$ $\mathrm{CO}_{2} \mathrm{OH}$ in $\mathrm{CHCl}_{3}$. The caryophyllene can be converted into oxide by adding $\mathrm{m}$ chlorobenzoic acid in $\mathrm{CH}_{2} \mathrm{Cl}_{2}$. Furthermore, if caryophyllene reacted with $\mathrm{Al}_{2} \mathrm{O}_{3}$ in the petroleum ether media to be obtained three alcohol mixture ${ }^{(18)}$.

Conversion caryophyllene oxide can be kobusan using ozone ${ }^{(38)}$. Kobusan can then be converted into an aldehyde mixture which has a woody musky odor by a series of reactions. Hydrolysis is catalyzed by $\mathrm{H}_{2} \mathrm{SO}_{4}$ to kobusan will produce a glycol. Glycol is obtained when oxidized with chromic acid will be produced oxoalcohol which later turned into diketone. The process is carried out by Barton et al $(1953)^{(39)}$ and Fitjer et al $(1995)^{(40)}$.

Research conducted by Yang and Dienar (1994) $)^{(41)}$ showed when caryophyllene oxide was refluxed for 3 hours in a solution of NaOAc / HOAc $(\mathrm{pH}$ 4) obtained six compounds. Analysis by GC-MS showed that the first four compounds have a molecular ion, $\mathrm{M}^{+}=\mathrm{m} /$ $\mathrm{z}=220$, while the last two compounds have a molecular ion $\mathrm{M}^{+}=\mathrm{m} / \mathrm{z}=238$. Asep, et. al, (2001) have done caryophyllene reaction with $\mathrm{O}_{2}$ by varying the temperature and reaction time ${ }^{(42)}$. Conversion caryophyllene to caryophyllene oxide obtained optimum results $84.1 \%$ when the reaction is performed at a temperature of $80{ }^{\circ} \mathrm{C}$ for 3.5 hours. Asep et al (2001) $)^{(42)}$ also perform synthesis using basic materials of caryophyllene and caryophyllene oxide to caryophyllene alcohol. In this study, using formic acid, acetic acid, and butyric acid.

\section{Derivation of Clove Oil by Biocatalysis}

In general biocatalysis or biotransformation can be defined as the use of biological systems (whole cells, cellular extracts or isolated enzymes) to catalyze the conversion of one compound to another ${ }^{(43-}$ 46). Similar to chemical catalysts, biocatalysts increase the speed in which a reaction takes place but do not affect the thermodynamics of the reaction ${ }^{(4)}$. Fermentation to produce alcohol and cheese production from milk protein was the examples of biocatalysis process that have been used since ancient time ${ }^{(45)}$. There is an increasing trend of investigation toward the utilization of biocatalysis potential for production value added products from conventional as well as nonconventional substrates $^{(46)}$. In Europa Bio 2003, biocatalysis represent the main pillar of applied biotechnology, which has been coined as "White Biotechnology" and which stands for the application of Nature's toolset to sustainable industrial production $^{(47)}$. Advantage of biocatalysis compare to chemical catalysis includes high chemo-, regio-, and stereo-selectivities; require mild reaction conditions; normally performed in an aqueous environment but can, in many cases, also be conducted in solvent mixtures, liquid- liquid two-phase 
systems, and even in pure organic solvents; there is no, or only limited use of protecting groups; when using whole cells as biocatalyst, more than one reaction can be accomplished as cell cultures can express a series of enzyme activities; the process of biocatalysis may be simple where the process is mediated by one or more enzymes with many steps; Single step biotransformation is comparatively efficient, as the yield decreased with increase in steps; natural or synthetic substrate can be used in biocatalysis; besides biocatalysis consider as more environmentally friendly ${ }^{(48-54)}$.

\section{Biocatalysis using plant and microorganism enzymes system}

Dimerization biocatalysis process of clove oil derivatives based on reaction using horseradish peroxidase (HRP) and $\mathrm{H}_{2} \mathrm{O}_{2}$ (Figure 10) follow by reaction with laccase to oxidise residual $\mathrm{H}_{2} \mathrm{O}_{2}$ can be conducted $^{(49-50)}$. The biocatalysis relied on HRP to oxidatively dimerise eugenol within the essential oil, this condition change the liquid soluble component into an unsoluble solid material, the product could be separated by filtration ${ }^{(49-50)}$. Using this process, biocatalysis to form eugenol dimer $^{(51-52)}$ and isoeugenol dimer ${ }^{(51)}$ have been reported. Other plant peroxidase enzymes preparation, such as from Indonesian vegetable "sawi hijau"(Brassica juncea) $)^{(53)}$ and from callus ${ }^{(54)}$ of alfalfa, arnica, gotu kola and bean. B. juncea peroxidase could also be used for dimeriztion of guaicol $^{(55)}$, whereas the callus of alfalfa, arnica, gotu kola and bean also reported for dimerization of vanillin ${ }^{(54)}$.

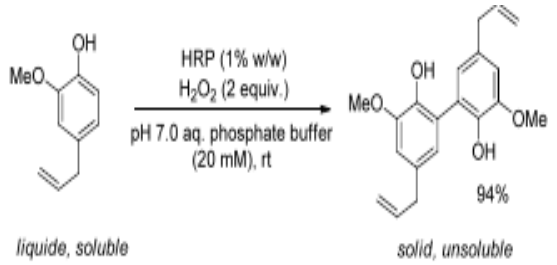

Figure 10. Dimerization of eugenol using HRP catalysis in the presence of $\mathrm{H}_{2} \mathrm{O}_{2}{ }^{(40)}$
$\mathrm{Wu}$ et al. reported studies on biocatalysis of clove oil into vanillin using soybean lipoxygenase (SBLOX) (Figure 11) as biocatalyst in a silicon rubber membrane bioreactor (SRMBR) and shaking flasks. The results showed that the vanillin conversion in SRMBR (121.53 $\mathrm{mg} / \mathrm{L}$ ) was much better than the conversion in shake flask $(8.14 \mathrm{mg} / \mathrm{L})$ after $36 \mathrm{~h}$, whereas the conversion rate of clove oil was $0.033 \%$ in the shaking flask and $1.01 \%$ in the SRMBR $^{(56)}$.

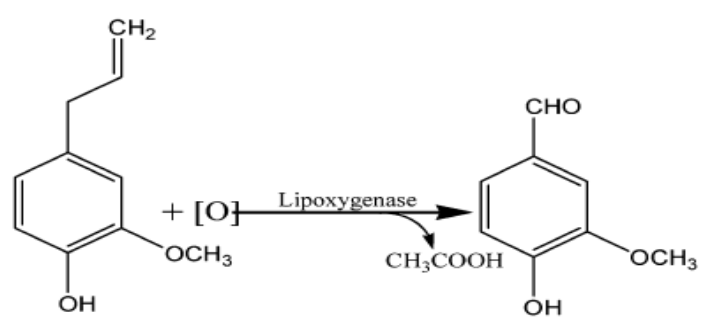

Figure 11. Bioconversion of eugenol into vanillin catalyszed by SBLOX ${ }^{(\mathbf{5 5})}$

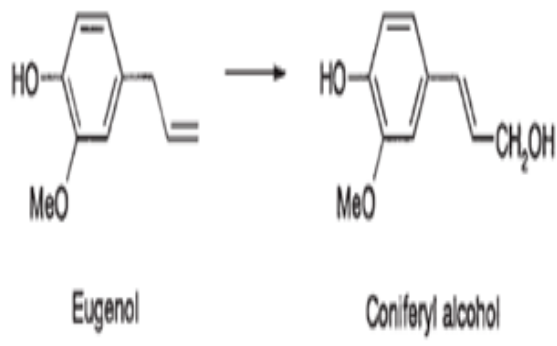

Figure 12. Biocatalysis of eugenol into coniferyl alcohol by eugenol dehydrogenase ${ }^{(\mathbf{5 6})}$

Microbial source also shows activities of several enzymes that could act as biocatalyst for biotransformation of clove oil derivatives. Eugenol dehydrogenase, the enzyme that catalyzes the conversion of eugenol to coniferyl alcohol (Figure 12) has been isolated and purified from Pseudomonas fluorescens E118 ${ }^{(56)}$. Activities of eugenol hydroxylase, feruloylCoA synthetase, vanillate-O-demethylase, and protocatechuate 3,4-dioxygenase have 
been detected in cell free extract of thermophilic Geobacillus sp. AY 946034 strain grown on eugenol ${ }^{(57)}$.

\section{Biocatalysis process using plant cell cultures system}

Plant cell cultures from nine plant species have been used to study the biocaltalysis system of eugenol and isoeugenol to form the dimers via the oxidative coupling reaction to develop an alternative to chemical methods for the synthesis of the bioactive compounds ${ }^{(58)}$. The species used are: alfalfa (Medicago sativa L.), bean (Phaseolus vulgaris), coriander (Coriandrum sativum), Psacalium peltatum, melon (Cucumis melo), carrot (Dacus carota), Prunus serotina, Mammillaria huitzilopochtli and Bouvardia ternifolia. The results showed that the all cell suspension cultures could transformed eugenol to produced dehydrodiugenol as the sole major product which coriander $(C$. sativum) produced the highest yield of dehydrodieugenol $(35 \%)^{(58)}$. Biocatalysis of eugenol to form biseugenol was also reported using Kalopanax pictus cell cultures which could produced $16.3 \mathrm{mg} / \mathrm{L}$ of biseugenol ${ }^{(54)(59)}$. Plant cells cultuted of Eucalyptus perriniana showed ability as biocatalyst for glycosylation reaction of isoeugenol and eugenol ${ }^{(60)}$. There were 5 biocatalysis products of isoeugenyl (Figure 13) and 3 biocatalysis product of eugenol (Figure 14) $)^{(60)}$. Later Shimoda et al. $(2006)^{(61)}$. reported that this plant cell cultured could transform eugenol to give yield of $7 \%$ eugenyl beta-glucoside and 58 $\%$ eugenyl beta-gentiobioside ${ }^{(61)}$. Glycosilation ability in biocatalysis of eugenol also reported in crown galls of Panax quinquefolium that could transform eugenol into 3 biocatalysis product namely 2-methoxy-4-(2-propenyl)phenyl-O-b-Dglucopyranoside $(67.11 \%)$, 2-methoxy-4(2-propenyl) phenyl-O-b-Dglucopyranosyl-b-D-xylopyranoside $\quad(2.85$ $\%)$ and methyl eugenol $(14.30 \%)$ and cell suspension cultures of Nicotiana tabacum that only could transform eugenol to 2methoxy-4-(2-propenyl)phenyl-O-b-Dglucopyranoside ${ }^{(62)}$.
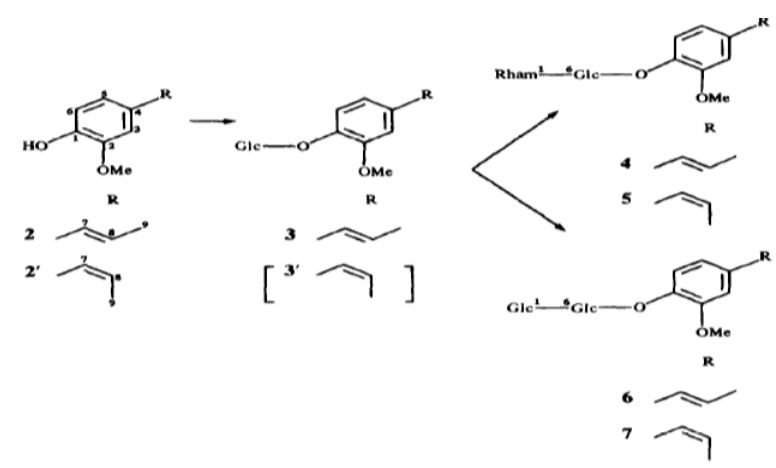

Figure I3. Biocatalysis of isoeugenol (cis and trans ratio 20:1) by $E$. perrinzana cell suspension cultures ${ }^{(60)}$. Trans isoeugenyl-beta-glucoside (3), transamd cis- isoeugenyl beta-rutinoside (4 and 5), trans-and cis isoeugenyl betagentiobioside (6 and 7)

\section{Biocatalysis Using Microbial Cultures System}

Currently there is an increase in demand for natural products, which lead to increase in studies of microbial as biocatalysis to convert simple metabolite into valuable metabolites that used in food and pharmaceutical industries. It has been reported that important value-added products such as coniferyl alcohol, coniferyl aldehydes, ferulic acid and vanillin were produced by microorganisms as biocatalysis product of eugenol ${ }^{(45)}$. Figure 15 show the pathway of microbial biocatalysis of eugenol to vanillin. Screening on enrichment culture applying eugenol as a sole carbon source resulted 8 eugenol-degrading microorganisms whereas Bacillus sp. strain BR showed the highest vanillin production. This microbe could act as biocatalyst to convert $0.0128 \mathrm{mM}$ eugenol to $0.32 \mathrm{mg} / 1$ vanillin after 48 hour incubation $^{(63)}$.

P. fluorescens E 118 cultures could act as biocatalyst of eugenol and clove oil to produce ferulic acid ${ }^{(64)}$. Using $26.6 \mathrm{~g}$ of 
clove oil resulted $11.6 \mathrm{~g}$ of ferulic acid in 2 L of culture broth ${ }^{(64)}$. . Geobacillus sp. AY 946034, a thermophilic bacterial strains was reported could grown in the media with eugenol lower than $0.02 \%$ and showed that the major metabolites of biotransformation products are protocatechuic acid, vanillic acid, coniferyl alcohol and ferulic acid $^{(57)}$. Studies of biocatalysis of eugenol to vanillin have been conducted using genetic engineered microorganism. Recombinant strain $\quad$ E. coli XL1-Blue (pSKvaomPcalAmcalB) converted eugenol to ferulic acid whereas $E$. coli (pSKech $\mathrm{E} / \mathrm{H} f c s$ ) was used to convert ferulic acid to vanillin ${ }^{(65)}$. . There are many other report of the use of microbial systems as biocatalysis of eugenol as shown in Table $2^{(45)}$.

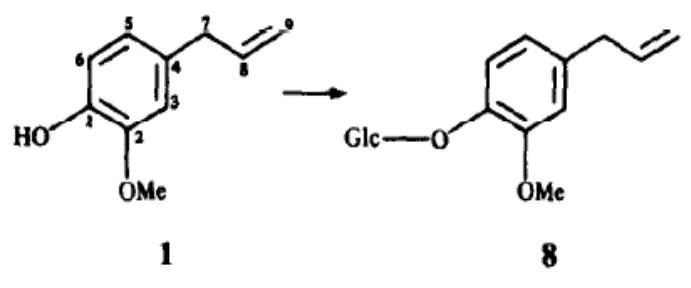

1

8

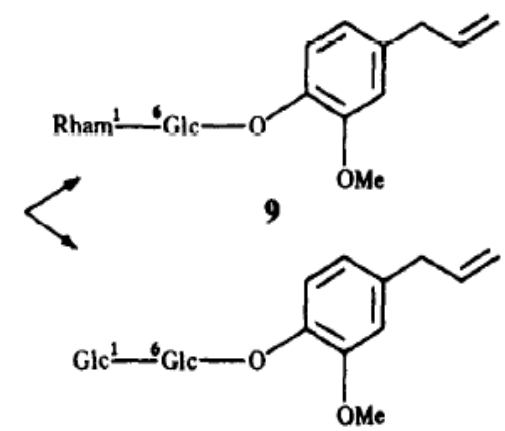

10

Figure 14. Biocatalysis of eugenol by E. perrinzana cell suspension cultures ${ }^{(60)}$. Eugenyl beta-glucoside (8). Eugenyl beta rutinoside (9) and eugenyl beta-gentiobioside (10)
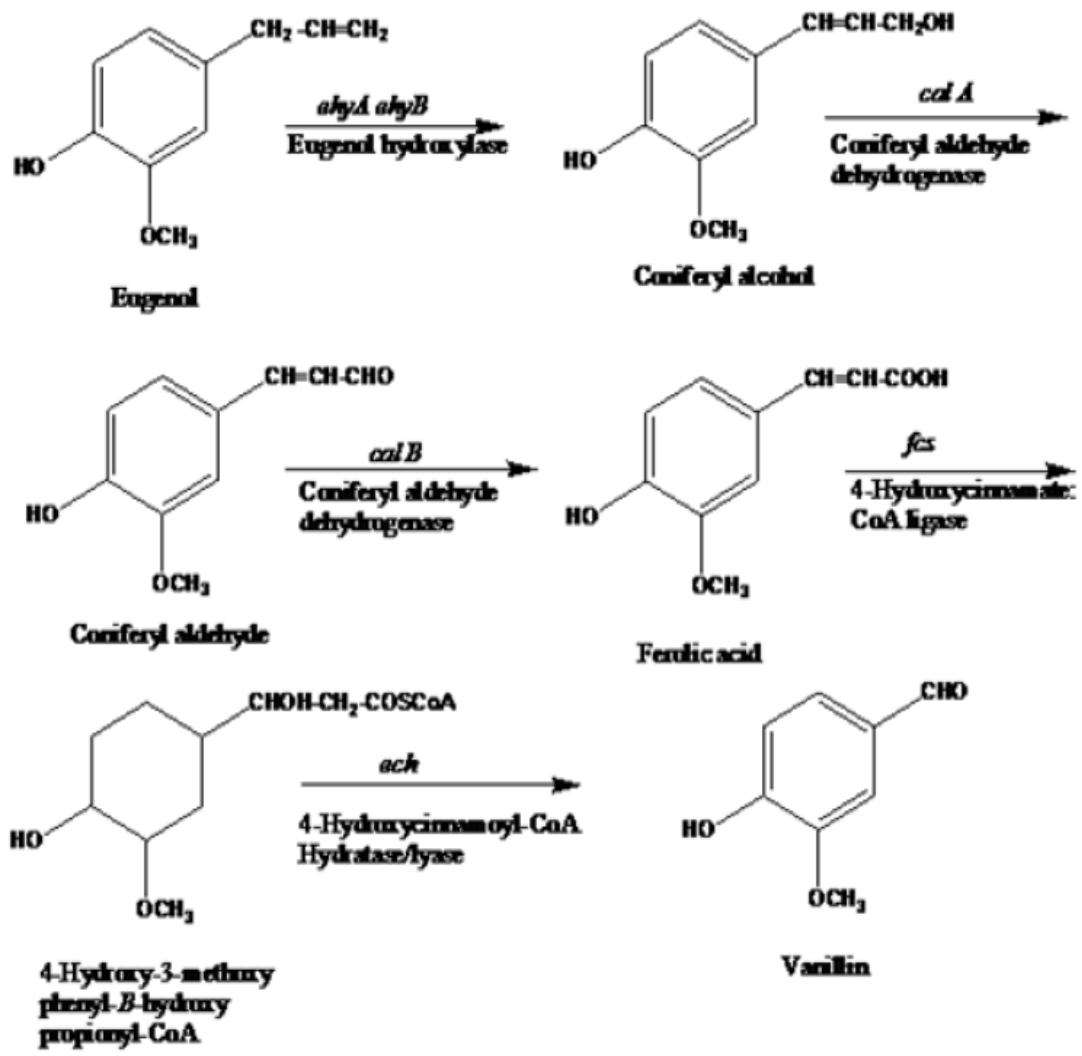

Varilin

Figure 15. Microbial biocatalysis of eugenol to vanilin ${ }^{(63)}$ 
Table 2. Microorganisms involved in biocatalysis of eugenol ${ }^{(45)}$

\begin{tabular}{|c|c|}
\hline Microorganisms & Products \\
\hline Corynebacterium sp. & $\begin{array}{l}\text { Ferulic acid, vanillin, vanillic acid, proocatechuic acid and keto adipic } \\
\text { acid }\end{array}$ \\
\hline Pseudomonas sp. & $\begin{array}{l}\text { Eugenol oxide, eugenol-diol, coniferyl alcohol, coniferyl aldehyde and } \\
\text { ferulic acid }\end{array}$ \\
\hline Enterobacter sp. & Vanillin \\
\hline Pseudomonas sp. & Coniferyl alcolohol, coniferyl aldehydes, ferulic acid and vanillic acid \\
\hline Pseudomonas sp. HR199 & $\begin{array}{l}\text { Ferulic acid, coniferyl alcohol, coniferyl aldehyde, vannilin and vanilic } \\
\text { acid }\end{array}$ \\
\hline $\begin{array}{l}\text { Ralstonia eutropha H16 } \\
\text { (GM) }\end{array}$ & Coniferyl alcolohol, coniferyl aldehydes and ferulic acid \\
\hline Escherichia coli $(\mathbf{G M})$ & Coniferyl alcolohol, coniferyl aldehydes, ferulic acid, and vanillin \\
\hline $\begin{array}{l}\text { Pseudomonas fluorescens } \\
\text { E118 }\end{array}$ & Coniferyl alcolohol \\
\hline $\begin{array}{l}\text { Amycoltopsis } \quad \text { sp. HR167 } \\
\text { (GM) }\end{array}$ & $\begin{array}{l}\text { Coniferyl alcolohol, coniferyl aldehyde, ferulic acid, guaiacol and vanillic } \\
\text { acid }\end{array}$ \\
\hline $\begin{array}{l}\text { Pseudomonas nitroreducens } \\
\text { Jin1 }\end{array}$ & Coniferyl alcolohol, ferulic acid, vanillin and vanillic acid \\
\hline Bacillus cereus PN24 & $\begin{array}{l}\text { 4-vinyl guaiacol, vanillin, vanillic acid, protocatechuic aid and keto-adipic } \\
\text { acid }\end{array}$ \\
\hline Streptomyces sp. & Coniferyl alcolohol, ferulic acid and vanillin \\
\hline $\begin{array}{l}\text { Pseudomonas resinobrans } \\
\text { SPR1 }\end{array}$ & $\begin{array}{l}\text { Coniferyl alcolohol, coniferyl aldehyde, ferulic acid, vanillin and vanillic } \\
\text { acid }\end{array}$ \\
\hline Pseudomonas sp. OPS1 & $\begin{array}{l}\text { Coniferyl alcolohol, coniferyl aldehyde, ferulic acid, vanillic acid and } \\
\text { protocatechuic acid }\end{array}$ \\
\hline
\end{tabular}

\section{CONCLUSION}

This review summarize information on various clove oil derivatives as well as various processes of clove oil derivatives using chemical catalysis and biocatalysis that will be useful to understand the current status and future prospect of many clove oil derivatives that was used as chemical industry aromatic clove oil derivatives in food, fragrance and pharmaceutical industries.

\section{REFERENCES}

1. M. S. Rusli, Potensi Minyak Atsiri Indonesia \& Peran DAI, disampaikan pada Seminar Sehari Prospek Pengembangan Bisnis Atsiri 2015, Bogor

2. Departemen Pertanian Republik Indonesia. Prospek dan Arah
Pengembangan Agribisnis Cengkeh. Badan Litbang Deptan. Jakarta, 2006.

3. Ketaren. Pengantar Teknologi Minyak Atsiri. Balai Pustaka, Jakarta Semangat, 1985.

4. E. Guenther, Minyak Atsiri. Jilid I. Terjemahan Ketaren S. UI Press. Jakarta, 1987.

5. A. Ruhnayat, Memproduktifkan Cengkih-Tanaman Tua, Tanaman Terlantar. Penebar Swadaya. Jakarta, 2002.

6. D. Arata., Adv. Catal, 37: 165 (1990)

7. T. Jin, T. Yamaguchi and K. Tanabe., J. Phys. Chem. 90: 4794 (1986)

8. Leody. Mempelajari Pembuatan Isoeugenol dari Minyak Daun Cengkeh. Skripsi. FATETA. IPB. Bogor. (1992)

9. Essential Oil Association. (1970) 
10. Aroma Indesso Indonesia. (2006)

11. T. Robinson, Kandungan Organik Tumbuhan Tinggi. Terjemahan dari The Organic Constituents of Higher Plants, $6^{\text {th }}$ ed. oleh Kosasih. Penerbit: ITB, Bandung. 1995.

12. S. Tursiloadi,, Highly Selective Heterogenous Nanocatalyst for The Synthesis of Pharmaceuticals from Clove Oil, Program Insentif KMNRT, (2010)

http://kimia.lipi.go.id/?page_id=5\&mod $\underline{\mathrm{e}=\text { detail \&ID=200. }}$.

13. M. Heitbaum, F. Glorius, I. Escher. Asymmetric Heterogeneous Catalysis. Angew. Chem. Int. Ed., 45: 4732 4762. (2006)

14. S. Sun, H. Zeng, Size-Controlled Synthesis of Magnetite Nanoparticles. $J$. AM. CHEM. SOC. 124: 8204-8205. (2002)

15. S. Tanaka, H. Hoh, Y. Akahane, S. Tsuts. Synthesis and reactions of heterodinuclear organopalladium-cobalt complexes acting as copolymerization catalyst for aziridine and carbon monoxide. Journal of Organometallic Chemistry. 692: 26-35. (2007)

16. S. Fujisawa, M. Ishihara, I. Yokoe. Computer-Aided Synthesis of Dimerized Eugenol. Journal of Molecular Design, 3, 241-246 (2004)

17. T. Ohkuma, H. Ooka, S. Hashiguchi, T. Ikariya, R. Noyori. Practical Enantioselective Hydrogenation of Aromatic Ketones. J. Am. Chem. SOC. 1995, 117: 2675-2616. (1994)

18. K. Arata, K. Hayono, dan H. Shirahana, Isomerization of Caryophyllene Oxide Catalyzed by Solid acids and Bases, Bull. Chem. Soc. Jpn, 66: 218-223. (1993)

19. J.R. Fessenden, J.S. Fessenden. Kimia Organik. Alih Bahasa Aloysius
Hadyana Pujaatmaka, edisi ketiga jilid I. Penerbit Erlangga, Jakarta. 1986.

20. M. Ogata. Antioxidant Activity of Eugenol and Related Monomeric and Dimeric Compound. Chem. Pharm. Bull. $\quad 48$ (10): 1467-1469. Pharmaceutical Society of Japan. Japan (2000)

21. N. Yamaguchi, S. Shimazu, N. Ichikuni, dan T. Uematsu. Synthesis of Novel Nano-structured Clays:Unique Conformation of Pillar Complexes. Chemistry Letters. 33 (3) (2004).

22. S. Shimazu, W. Teramoto, M. Miura, and T. Uematsu, J.Mater. Sci. Lett., 8: 1368 (1989).

23. A. Vaccari, Catal. Today, 41, 53 (1998).

24. F.A. Cotton, G. Wilkinson, \& P.L. Gaus. Basic Inorganic Chemistry. John Wiley \& Sons. New York. 1987.

25. T. Yamaguchi, Appl. Catal. 61, 1. 1990.

26. S. Tursiloadi. Mesoporous oxide materials based on the sol-gel method, Lambert Academic Publishing AG \& Co.KG. Dudweiler Landstr, ISBN 9783-8383-3345-8. Saarbrucken, Germany. 2010 .

27. M. Hino., S. Kobayashi, and K. Arata., J. Am. Chem. Soc. 101, 6439 (1979).

28. Hardjono Sastrohamidjojo, Produk Turunan Minyak Atsiri Dan Potensi Pasar, Program Studi Ilmu Kimia FMIPA UII, disampaikan pada Seminar Sehari Prospek Pengembangan Bisnis Atsiri 2015, Bogor, (2015)

29. J.R. Fessenden, J.S. Fessenden. Kimia Organik. Alih Bahasa Aloysius Hadyana Pujaatmaka, edisi ketiga jilid I. Penerbit Erlangga, Jakarta. 1986.

30. A. Marques, Fabio, Alfredo, George dan Paulo. Oxidative Coupling of 4Substitued 2-Methoxy Phenols Using Methyltributylammonium

Permanganate in Dichloromethane. 
Universidade Federal do Parana. Brasil. Tetrahedron Letters. 39: 943-946. (1997)

31. Y. Anita, Produksi Senyawa Bioaktif dari Reaksi Guaiakol dengan Enzim Peroksidase dan Uji Aktivitas Alelopati. Skripsi. Jurusan Kimia. Universitas Indonesia. Depok. (2004)

32. M. Irawati. Isolasi, Identifikasi dan Uji Aktivitas Antioksidan Senyawa Kimia dalam Ekstrak Metanol Rimpang Temu Kunci (Boesenbergia Pandurata(Roxb.) Schlecht). Skripsi. Fakultas Farmasi. Universitas Pancasila. Jakarta. (1999)

33. F. Dias. An Improved High Yield Synthesis of Dehydrodieugenol. Phytochemistry. 27 (9), 3008-3009. (1998)

34. H. Sastrohamidjojo. A Study of Some Indonesian essential Oil, Disertasi. Universitas Gadjah Mada, Yogyakarta. (1981)

35. H. Sastrohamidjojo., Kimia Minyak Atsiri, F.MIPA. Universitas Gadjah Mada, Yogyakarta. (2002)

36. D.H.R. Barton, A. Aebi, dan Lindsey. Journal of the Chem Soc. (1952)

37. Gildemeister and Hoffmaan,. Oils of Mentha species. In: Treibs, W., ed. Die Atherischen Ole. Akademic Verlag, Berlin, Germany, 7: 246-421. (1961)

38. B. Maurer, dan A. Hauser, New Constituen of Clary Age Oil, IX ${ }^{\text {th }}$, International Congress of Essential Oils, Singapore. 1983.

39. D.H.R. Barton, A. Aebi, dan Lindsey.. Journal of the Chem Soc. (1953)

40. L. Fitjer, M. Majewski, H. MonzoOltra. Tetrahedron. 51: 8835-8852 (1995)

41. Yang, X., and Deiner, M., Hydrolysis and Rearrangement Reactions of Caryophyllene Oxide, J. of Natural Product, 57 (4): 514-517. (1994).
42. Asep et al, Synthesis of Clovanadiol from Caryophyllene, International Seminar On Organic Chemistry Proceeding, Yogyakarta. 2001.

43. O. Ghisalba, H. Meyer, \& R.

Wohlgemuth. Industrial

Biotransformation. P1-18.

Encyclopedia of Industrial

Biotechnology: Bioprocess,

Bioseparation, and Cell Technology,

edited by Michael C. Flickinger John

Wiley \& Sons, Inc. 2010.

http://bio.lonza.com/uploads/tx_mwaxm arketingmaterial/LonzaWhite Papers

Industrial_Biotransformation.pdf

44. T. Johannes, M.R. Simurdiak, H. Zhao. Biocatalysis. (In Encyclopedia of Chemical Processing). Taylor \& Francis. 2006. pp. 101-110.

45. S. Mishra, A. Sachan •\& S.G. Sachan. Production of natural value-added compounds: an insight into the eugenol biotransformation pathway. $J$ Ind Microbiol. Biotechnol. 40:545-550. (2013)

46. K. Faber, Biotransformations in Organic Chemistry. A Textbook. Sixth revisedand corrected edition. ISBN 9783-642-17392-9 e-ISBN 978-3-64217393-6. Springer-Verlag Berlin Heidelberg. 2011. 423 pages. http://fs1.uclg.ru/books/pdf/1356681024 Faber_K._Biotransformations_in_Orga nic Chemistry_(6th_Ed.) [2011,_ENG].pdf diakses 7des14

47. V. Dave, P. Khirwadkar, K. Dashora. A review on biotransformation. Indian Journal of Research in Pharmacy and Biotechnology. ISSN: 2321-5674 (Print) ISSN: 2320 - 3471(Online) IJRPB 2(2) www.ijrpb.com. March - April 2014: 1136 (2014).

http://ijrpb.com/current\%20issues/1/v2 is2/ijrpb\%202(2)\%2012\%20praveen\%2 0khiridwadkar 
48. S. Antoniotti. Review Tuning of Essential Oil Properties by Enzymatic Treatment: Towards Sustainable Processes for the Generation of New Fragrance Ingredients. Molecules 19(7): 9203-9214. (2014)

49. A. Groussin dan S. Antoniotti. Valuable chemicals by the enzymatic modification of molecules of natural origin: Terpenoids, steroids, phenolics and related compounds. Bioresource Technology. 115: 237-243. (2012)

50. D. Elvi. The Synthesis Dimer Compound from Eugenol and Isoeugenol catalyzed Peroxidase Enzyme from Horseradish plant and antioxidant activity test. M.Sc.Thesis. University of Indonesia (2010)

51. C. Bouhlel, G.A. Dolhem, X. Fernandez, S. Antoniotti. Model study of the enzymaticmodification of natural extracts: Peroxidase-based removal of eugenol from rose essential oil.J. Agric. Food Chem., 60: 1052-1058. (2012)

52. Dehydrodieugenol, (bieugenol, 3,3dimethoxy-5,5- di-2-propenyl-1,1biphenyl-2,2 diol) for Anti Bacterial Agent in Dental Filling Material Application. 5th TMDU (Tokyo Medical and Dental University) International Summer Program (ISP2013) Biomaterials: From the Laboratory to the Clinic, $26-29$ August 2013

53. L. Hernández, H. Luna, M.T. Olivera, A. Navarro, J. Cassani, L. Hernandez. Oxidative Coupling Of Natural Phenols Biocatalyzed By Plant Enzymatic Preparations With Peroxidase Activity. XV Congreso Nacional de Biotecnología y Bioingeniería Cancún, México GIMI0864 - (2013)

54. G.Widiyarti, J. Abbas, Y. Anita. Biotransformation and Cytotoxic Activity of Guaiacol Dimer. Indo. J. Chem., 14 (2), 179 - 184. (2014)
55. Y. Wu, M. Feng, W. Ding, X. Tang, Y. Zhong, Z. Xiao. Preparation of vanillin by bioconversion in a silicon rubber membrane bioreactor. Biochem. Eng. J. 41 193-197. (2008)

56. H. Furukawa, M, Wieser, H. Morita, T. Sugio, T. Nagasawa. Purification and characterization of eugenol dehydrogenase from Pseudomonas fluorescens E118. Arch Microbiol. $171: 37-43$. (1998)

57. G. Giedraityte, dan L. Kaldiene. Biotransformation of Eugenol via Protocatechuic Acid by Thermophilic Geobacillus sp. AY 946034 Strain. J. Microbiol. Biotechnol., 24(4):475-482. (2014).

58. L. Hernández-Vázquez, M.T.J. OliveraFlores, F. Ruíz-Terán, I. Ayala, A Navarro-Oca na. Screening of plant cell cultures for their capacity to dimerize eugenol and isoeugenol: Preparation of dehydrodieugenol. $J$. Mol. Catalysis B: Enzymatic 72: 102106. (2011)

59. B.G. Kim, J.Y. Kim, Y. Yi, Y. Lim. Biotransformation of eugenol to biseugenol by Kalopanax pictus cell culture. J. Korean Soc. Biol. Chem. 55(5): 677-680 (2012).

60. Y. Orihara, T. Furuya, N. Hashimoto, Yuichi Deguchi, K. Tokorot And T. Kanisawa. Biotransformation Of Isoeugenol And Eugenol By Cultured Cells Of Eucalyptus perriniana. Phytochemistry, 31(3): 827-831 (1992)

61. K. Shimoda, Kondo Y, Nishida T, Hamada $\mathrm{H}$, Nakajima $\mathrm{N}$, Hamada $\mathrm{H}$. Biotransformation of thymol, carvacrol, and eugenol by cultured cells of Eucalyptus perriniana. Phytochemistry. Oct;67 (20):2256-61. Epub 2006 Aug 22. (2006).

62. L. Yang, C. Yan, J. Zhu, L. Song, R. Yu. Biotransformation of eugenol by suspension cultures of transgenic crown 
galls of Panax quinquefolium and suspension cultures of Nicotiana tabacum. World J Microbiol Biotechnol 26:1201-1205. (2010)

63. G. Sindhwani, I. Uk and V. Aeri. Microbial transformation of eugenol to vanillin. J. Microbiol. Biotech. Res., 2 (2):313-318. (2012)

64. H. Furukawa, S. Zenno, I. Yumiko, H. Morita, T. Yoshida, dan O. Nagasawa. Ferulic Acid Production From Clove Oil By Pseudomonasm fluorescens E 118. Biosci. Bioeng. 96 (4): 404-405. (2003).

65. Overhage, J. A. Steinbu“chel, dan H. Priefert. Highly Efficient Biotransformation of Eugenol to Ferulic Acid and Further Conversion to Vanillin in Recombinant Strains of Escherichia coli Applied Environ. Microbiol, 65696576 (2003). 